\title{
In Vitro Growth Rate of Placental Fibroblasts Is Developmentally Regulated
}

\author{
Michael E. Fant \\ Department of Pediatrics, University of Texas Southwestern Medical School, Dallas, Texas 75235
}

\begin{abstract}
Placental cells of mesenchymal origin were used to study the regulation of fetal growth at the cellular level. A significant difference in the in vitro growth rates of placental fibroblasts was observed as a function of gestational age. Cells derived from 10-19-wk placentae exhibited proliferative rates two to three times greater than cells derived from 7-9-wk placentae (16-30 h vs. 30-60 h, $P<0.001$ ). The proliferation rate remained stable throughout multiple passages in culture. Additionally, these two groups of cell strains exhibited marked differences in their responsiveness to mitogenic stimuli. Using maximal effective concentrations, insulin-like growth factor I interacted synergistically with epidermal growth factor and fibroblast growth factor to stimulate DNA synthesis in cells derived from 10-19-wk placentae. By contrast, the interaction of insulin-like growth factor 1 with epidermal growth factor and fibroblast growth factor exhibited significantly less synergy in 7-9-wk cells. These findings argue that the accelerated growth rate of human fetal cells results primarily from developmental events intrinsic to the cells and is associated with enhanced responsiveness to the mitogenic action of peptide growth factors. (J. Clin. Invest. 1991. 88:1697-1702.) Key words: placenta $\cdot$ growth $\cdot$ mitosis
\end{abstract}

\section{Introduction}

Normal fetal growth results from the normal progression of discrete developmental events that occur throughout gestation. The degree to which fetal growth results from a developmental "program" intrinsic to the fetus or is regulated by maternal or other external factors is not known. This is understandable since the cellular mechanisms comprising normal embryonic and fetal development are not fully understood. A major developmental event occurs at $\sim 10$ wk gestation when an acceleration in fetal growth velocity takes place (1). This acceleration represents not only total fetal weight but is due primarily to cellular hyperplasia in fetal organs (2). While the molecular basis for this accelerated growth is unknown, possible regulatory roles for tissue growth factors and cellular oncogenes during fetal development have been postulated (3-5).

This work was presented in part at the 58th annual meeting of the Society for Pediatric Research, Washington, DC, 1-4 May, 1989.

Address correspondence to Michael E. Fant, M. D., Ph. D., Department of Pediatrics, University of Texas Southwestern Medical School, 5323 Harry Hines Boulevard, Dallas, TX 75235. 1991.

Received for publication 10 July 1990 and in revised form 14 May

J. Clin. Invest.

(c) The American Society for Clinical Investigation, Inc.

0021-9738/91/11/1697/06 \$2.00

Volume 88, November 1991, 1697-1702
The placenta is a logical source of fetal cells to study the cellular mechanisms regulating fetal growth. It is the only fetal organ whose sole function is to maintain an optimal milieu for fetal development. Consequently, fetal growth is dependent upon placental well-being. Like other fetal tissues the placenta undergoes a specific sequence of growth and differentiation over a short time period (6). Specifically, the placenta undergoes a similar acceleration in growth rate at the end of the first trimester (7). Since tissue-specific mesenchymal cells are essential for normal organ development (8) placental fibroblasts were used as a model system to begin studying the cellular mechanisms regulating human placental growth.

\section{Materials}

Sources of material. Term placental tissue was obtained from normal, nonlabored pregnant women undergoing repeat caesarean section at 38-41 wk gestation. Preterm placental tissue was obtained from elective therapeutic abortions between 7 and 19 wk gestation. Placentae were obtained in accordance with a protocol and consent form approved by the Institutional Review Board of the University of Texas, Southwestern Medical Center, Dallas, Texas. Dulbecco's modified Eagle's medium, penicillin, streptomycin, fetal calf serum, nystatin, and all plastic culture dishes were purchased from Gibco Laboratories, Grand Island, NY. BSA-RIA grade was obtained from Sigma Chemical Co., St. Louis, MO. Epidermal growth factor (EGF) ${ }^{1}$ and fibroblast growth factor (FGF) were obtained from Collaborative Research, Inc., Waltham, MA. Synthetic, human insulin-like growth factor I (IGF-I) was purchased from Bachem, Inc., Torrance, CA. Carrier-free [ $\left.{ }^{125} \mathrm{I}\right]-$ $\mathrm{Na}$, [ $\left.{ }^{125} \mathrm{I}\right]-\mathrm{EGF}(2,200 \mathrm{Ci} / \mathrm{mmol})$, and $\left[{ }^{3} \mathrm{H}\right]$-thymidine were purchased from DuPont New England Nuclear Corp., Boston, MA. Peroxidaseantiperoxidase immunohistochemical staining kits for vimentin, desmin, and a human chorionic gonadotropin (HCG) were obtained from Accurate Chemical Scientific Corp., Westbury, NY. Peroxidase-antiperoxidase immunohistochemistry kits for factor VIII antigen and cytokeratin were obtained from Dako Corp., Santa Barbara, CA.

Placental fibroblast culture. Placental tissue, dissected free of decidua and membranes, was subjected to enzymatic digestion for $30 \mathrm{~min}$ at $37^{\circ} \mathrm{C}$ by $0.1 \%$ collagenase, $0.1 \%$ hyaluronidase, and $0.01 \%$ DNase in $\operatorname{DMEM}(5 \mathrm{ml} / \mathrm{gm})$. The dispersed cells were filtered through a $150-\mu \mathrm{m}$ nylon mesh. The cells were centrifuged $(100 \mathrm{~g})$, resuspended in $10 \mathrm{ml}$ DMEM containing $10 \% \mathrm{FCS}$, penicillin $(100 \mathrm{U} / \mathrm{ml})$, streptomycin $(100$ $\mu \mathrm{g} / \mathrm{ml}$ ), and seeded into T-25 culture flasks. The cells were allowed to attach overnight. The media were changed the next day and every 3-4 $\mathrm{d}$ thereafter. The fibroblastoid cells proliferated while the trophoblasts tended to degenerate during the second week of culture. When confluent the cells were passaged in a 1:4 split ratio. By the second passage an apparently homogeneous population of fibroblastoid cells remained. The fibroblasts were grown in T-75 flasks in DMEM, $10 \%$ FCS, in a humidified incubator containing $5 \% \mathrm{CO}_{2}$. The medium was harvested every 3-4 d. The cells were removed by trypsinization and replated every week (1:4 passage dilution).

Characterization of cell strains. Mesenchymal cells were isolated from the chorionic villi of human placentae at $7-19 \mathrm{wk}$ gestation. Ges-

1. Abbreviations used in this paper: EGF, epidermal growth factor; FGF, fibroblast growth factor; GF, growth factor; HCG, human chorionic gonadotropin. 
tational age was determined by maternal dates and confirmed by foot length measurements (9) when possible. The cells were grown in DMEM supplemented with $10 \%$ FCS from identical lots in most cases. Otherwise, only lots that performed similarly in growth-promoting assays were used. Cells were used for growth studies between the third and seventh passages. The cells were characterized by immunohistochemical techniques as described later. The fibroblastoid character of cells derived from 9- and 19-wk placentae was confirmed by the positive staining of vimentin along with negative staining for desmin, factor VIII antigen, keratin, and a-HCG. This screen effectively ruled out the presence of differentiated vascular smooth muscle cells, endothelial cells, and trophoblasts (10-12). Additionally, each cell strain was karyotyped. Only cell strains with normal chromosomes by karyotype analysis were included in these studies.

Cellular binding of $\left[{ }^{125} I\right]-I G F-I$ and $\left[{ }^{125} I\right]-E G F$. IGF-I was iodinated to a sp act of $200-300 \mu \mathrm{Ci} / \mu \mathrm{g}$ by a modification of the chloramineT procedure of Hunter and Greenwood (13), as described by Rechler et al. (14). Fibroblasts of $15 \mathrm{wk}$ gestation were grown to confluence in $1.6-\mathrm{cm}$ wells as described. The medium was changed to serum-free medium and incubated further for $48 \mathrm{~h}$. After $48 \mathrm{~h}$ the cells were washed with serum-free medium and incubated with IGF-I (100 ng/ $\mathrm{ml})$, EGF $(10 \mathrm{ng} / \mathrm{ml})$, or control medium for $4 \mathrm{~h}$. The cells were then washed three times with Earle's balanced salt solution, $\mathrm{pH}$ 7.4. Radiolabelled IGF-I or EGF $(20,000-30,000 \mathrm{cpm})$ and various concentrations of unlabelled, homologous peptide were added to each well in triplicate to a final volume of $1.0 \mathrm{ml}$ Earle's balanced salt solution, $\mathrm{pH}$ 7.4. The cells were incubated for $16-20 \mathrm{~h}$ at $4^{\circ} \mathrm{C}$, washed, solubilized with $1 \mathrm{~N} \mathrm{NaOH}$, and counted. Specific binding was determined by the difference in binding in the presence and absence of $100 \mathrm{ng}$ unlabelled homologous ligand. Binding to the cells was analyzed by Scatchard analysis.

Receptor crosslinking. Placental fibroblasts were grown to confluence in 24-well plates in DMEM, 10\% FCS. The cells were then washed and incubated in the presence or absence of $\operatorname{EGF}(10 \mathrm{ng} / \mathrm{ml})$ or FGF $(100 \mathrm{ng} / \mathrm{ml})$ for $4 \mathrm{~h}$ at $37^{\circ} \mathrm{C}$. The cells were washed twice with ice cold phosphate buffered saline and incubated $16 \mathrm{~h}$ at $4^{\circ} \mathrm{C}$ in $0.5 \mathrm{ml}$ binding buffer $\left(0.1 \mathrm{M}\right.$ Hepes, $0.12 \mathrm{M} \mathrm{NaCl}, 5 \mathrm{mM} \mathrm{MgSO}{ }_{4}, 8 \mathrm{mM}$ glucose, $5 \mathrm{mg} / \mathrm{ml} \mathrm{BSA,} \mathrm{pH} \mathrm{8.0)} \mathrm{containing} 500,000 \mathrm{cpm}$ [ $\left.{ }^{125} \mathrm{I}\right]-\mathrm{IGF}-\mathrm{I}$. At that time $0.4 \mathrm{ml}$ disuccinimidyl suberate was added at a concentration of $0.200 \mathrm{mM}$ and incubated for $15 \mathrm{~min}$ at room temperature. The reaction was quenched with $1.2 \mathrm{ml}$ ice cold $10 \mathrm{mM}$ Tris/1 mM EDTA. The cells were solubilized in $75 \mu 12 \%$ SDS, $100 \mathrm{mM}$ dithiothreitol. Lysates from three wells were pooled, transferred to $1.5-\mathrm{ml}$ microfuge tubes, and boiled for $3 \mathrm{~min}$. The lysates were subjected to $10 \%$ SDSPAGE. The gels were dried and subjected to autoradiography in the presence of Dupont intensifying screens at $-80^{\circ} \mathrm{C}$.

Thymidine incorporation. Confluent monolayers of placental cells (passage 4-6) were placed in serum-free medium (SFM), 0.1\% BSA, for $48 \mathrm{~h}$ in 24-well plates. The quiescent cells were then washed and refed with SFM, $0.1 \%$ BSA plus test hormones. The cells were incubated further for $24 \mathrm{~h}$. Time course experiments in 9-wk and 19-wk fibroblasts revealed maximum DNA synthesis at 20-28 h. Within that time $0.5 \mu \mathrm{Ci}\left[{ }^{3} \mathrm{H}\right]$-thymidine was added to each well and incubated further for $4 \mathrm{~h}$. The cells were then washed, extracted with $10 \%$ TCA, solubilized in $1 \mathrm{M} \mathrm{NaOH}$, and counted. Data are represented as the mean $\pm \operatorname{SEM}(n=3)$.

Doubling times. Placental cells were seeded at a density of 100,000 cells/60-mm dish in DMEM containing 10\% FCS. After overnight attachment the cells of three dishes were washed, trypsinized, and counted using a hemocytometer. In three tandem dishes the media were replaced with DMEM, 10\% FCS. After $48 \mathrm{~h}$ further incubation, the cells in each dish were counted and averaged. The doubling time was estimated from the increase in cell number during that 48 -h period. Preliminary experiments revealed that the doubling time determined between days 1 and 3 was identical to that obtained between days 3 and 5. Therefore all subsequent determinations were derived from cell counts on days 1 and 3. Doubling times from at least three passages between the third and seventh passage were determined and averaged.
The data are expressed as the mean $\pm \operatorname{SEM}(n=$ single determinations over three to four passages).

Immunohistochemical staining. Placental cells were plated onto glass cover slips. The cells were grown for 2-4 $\mathrm{d}$ and fixed in Bouin's solution for $30 \mathrm{~min}$. After fixation, the cells were rinsed and stored at $4^{\circ} \mathrm{C}$ in PBS for $2-5 \mathrm{~d}$ before staining. The cells were stained using commercially available kits according to instructions. Keratin, factor VIII antigen, and desmin kits were obtained from Dako Corp. Kits for vimentin and a-HCG were obtained from Accurate Chemical \& Scientific Co. Paraffin sections of 13-wk placental tissue were used as control references for identifying cell types.

Cell cycle analysis. Placental fibroblasts were grown as described above. Confluent cells were trypsinized and replated at a low density of 1,000 cells $/ \mathrm{cm}^{2}$ in DMEM, $10 \%$ FCS. The cells were allowed to attach overnight and the media were changed. The cells were then allowed to grow in DMEM, 10\% FCS, for 48 additional hours to allow the cells to achieve exponential growth and a random distribution throughout the cell cycle. They were then rinsed and fixed with $70 \%$ ethanol for 30 $\mathrm{min}$. The cells were further incubated with $100 \mu \mathrm{g} / \mathrm{ml} \mathrm{mithramycin} \mathrm{in}$ $50 \mathrm{mM}$ Tris $/ 20 \mathrm{mM} \mathrm{MgCl}$, $\mathrm{pH} 7.4$ for an additional $30 \mathrm{~min}$ at $22^{\circ} \mathrm{C}$ essentially as described (15). The stained, attached cells were scanned with an Interactive Laser Cytometer (ACAS 570; Meridian Instruments, Inc., Okemos, MI) with a wavelength of $457 \mathrm{~nm}$ and the $\times 20$ microscope objective. Fluorescence emission at $530 \mathrm{~nm}$ was collected by a photomultiplier tube and digitized by a 16-bit microcomputer. Pseudocolor fluorescence intensity maps of the stained nuclei were displayed and DNA fluorescence histograms were obtained. The percent of cells in $\mathrm{G} 1, \mathrm{~S}$, and $\mathrm{G} 2 / \mathrm{M}$ were estimated by assuming normal distributions for the $G 1$ and $G 2 / M$ peaks as described (16). At least 1,000 cells were counted per cell strain for analysis. Absolute phase times were calculated from the phase distribution based upon the following relationships:

1. $T_{\mathrm{G} 1} / T_{\mathrm{C}}=-1 / \ln 2 \times \ln \left(1-F_{\mathrm{G} 1} / 2\right)$

2. $T_{\mathrm{S}} / T_{\mathrm{C}}=-1 / \ln 2 \times \ln \left(1-F_{\mathrm{G} 1} / 2-F_{\mathrm{S}} / 2\right)-T_{\mathrm{G} 1} / T_{\mathrm{C}}$

3. $T_{\mathrm{G} 2} / T_{\mathrm{C}}=1-T_{\mathrm{S}} / T_{\mathrm{C}}-T_{\mathrm{G} 1} / T_{\mathrm{C}}$.

This model assumes that the cells are in steady state, asynchronous, exponential growth (16). $T_{\mathrm{C}}$ represents the time required to traverse the complete cell cycle and was taken from the doubling time calculated from direct cell counts as described above during the same passage as the cell cycle analysis.

Statistical analysis. Differences between groups were analyzed using Student's $t$ test.

\section{Results}

Doubling times of placental fibroblasts. Growth patterns of the placental cells were studied by measuring their doubling time under uniform culture conditions. As seen in Fig. $1 A$, the doubling times of cells derived from 10-19-wk placentae $(21.6 \pm 1.7 \mathrm{~h})$ were much shorter than those exhibited by the $7-9$-wk gestation cells $(53.4 \pm 1.4 \mathrm{~h})$. The increased rate of proliferation was observed to occur at $10 \mathrm{wk}$ gestation. When the cell strains derived from placentae of 7-9 wk gestation were compared to those derived from 10-19-wk placentae, the difference in their doubling times was significantly different (Fig. $1 B, P$ $<0.001$ ). Additionally, the increased growth rate was "remembered" throughout multiple passages in culture (Fig. 2). Because these studies were done using identical or similar lots of fetal bovine serum, the increased proliferative rate appeared to be an intrinsic quality of the cells that was expressed from one generation to the next. Each cell strain was chromosomally normal by karyotype analysis. While this doesn't rule out all potential genetic lesions, it does point to developmental age as the most likely variable related to the observed change in proliferative rate. 


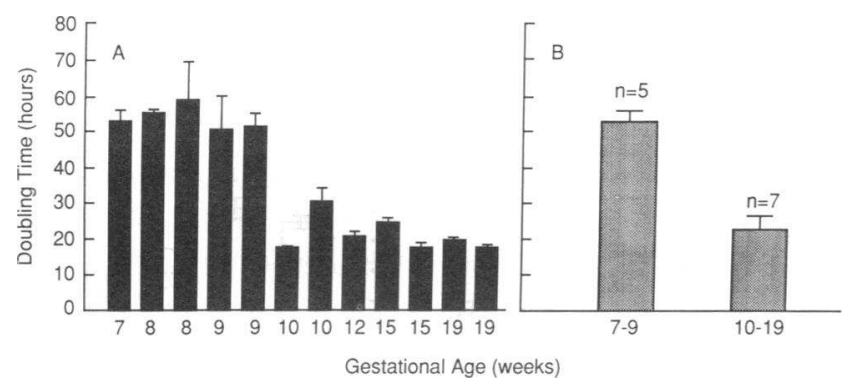

Figure 1. (A) Doubling times of placental fibroblasts at various gestational ages. Doubling times from at least three passages between the third and seventh passage were determined and averaged for one cell strain at each gestational age. The data are expressed as the mean $\pm \operatorname{SEM}(n=3-4)$. (B) Average doubling times of placental fibroblasts shown in $A$ were grouped according to gestational age range (7-9 wk and 10-19 wk) and averaged. The difference between the means of the two groups is statistically significant $(P<0.001)$.

Cell cycle analysis performed on mithramycin-stained cells revealed that rapidly growing cells (15 and 19 wk) exhibited much shorter $\mathrm{G} 1$ phases than the more slowly growing cells at 7 and 8 wk gestation (10-13 h vs. $40-47$ h, Table I). The G2/M phase was also somewhat shorter suggesting the presence of a G2 restriction point in these cells. It appears, however, that the major difference in cycling time for these two groups of cells resides in the length of $\mathrm{Gl}$.

Cellular responsiveness to growth factors. To determine if the enhanced proliferative rates of the cell strains could be explained, in part, by altered responsiveness to specific peptide growth factors (GF), the abilities of IGF-I, EGF, and FGF to stimulate DNA synthesis in these cells were tested. Each GF alone was capable of stimulating DNA synthesis in a dose-dependent manner. While the dose response curve for each GF was the same in both groups of cells, the cells derived from 10-19-wk placentae tended to have a greater maximum response than the cells studied at earlier gestations. It was difficult to quantify this difference, however, because of the significant variation exhibited by individual cell strains between experiments. The basal activity was similar in both groups of cells. When various combinations of GFs were tested at maximal stimulating doses, however, a major difference was noted between the two groups of cells. The combinations of IGF-I + EGF and IGF-I + FGF resulted in apparent additive stimulation of DNA synthesis in cells derived from an 8-wk placenta (Fig. $3 \mathrm{~A}$ ). The same combinations of GFs, by contrast, inter-

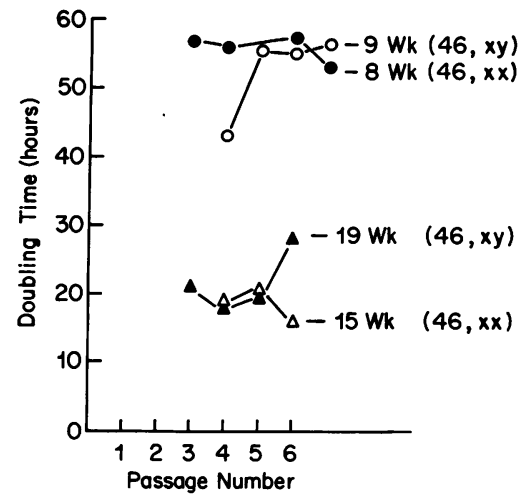

Figure 2. Proliferative rate of placental fibroblasts during serial passage in culture. Doubling times were determined during successive passage in culture on cells derived from one placenta each of 8,9 , 15 , and 19 wk gestation. Data represent the mean \pm SEM.
Table I. Cell Cycle Phase Duration* of Placental Fibroblasts

\begin{tabular}{lcccc}
\hline Cell strain & $\mathrm{T}_{\mathrm{c}}$ & $\mathrm{T}_{\mathrm{G} 1}$ & $\mathrm{~T}_{\mathrm{s}}$ & $\mathrm{T}_{\mathrm{G} 2 \mathrm{M}}$ \\
\hline $7 \mathrm{wk}$ & 58.9 & $46.6(0.85)$ & $4.1(0.05)$ & $8.2(0.10)$ \\
$8 \mathrm{wk}$ & 55.9 & $41.5(0.81)$ & $4.9(0.07)$ & $9.5(0.12)$ \\
$15 \mathrm{wk}$ & 19.0 & $11.0(0.66)$ & $6.0(0.26)$ & $2.0(0.13)$ \\
$19 \mathrm{wk}$ & 21.5 & $12.2(0.65)$ & $6.0(0.24)$ & $3.3(0.11)$
\end{tabular}

* Data expressed in hours. Number in parentheses is the fraction of cells in phase.

acted synergistically in cells derived from a 19-wk placenta (Fig. $3 \mathrm{~B}$ ). When the combination of IGF-I and EGF was tested in the other cell strains, a much stronger interaction was consistently observed in cells derived from 10-19-wk placentae compared to the responses observed in cells derived from 7-9-wk placentae (Fig. $4 A$ ). When the 7-9-wk cells were compared to the 10-19-wk cells the difference in their responsiveness was statistically significant (Fig. $4 \mathrm{~B}$ ). Similar gestational age-dependent differences in the cellular responsiveness were seen with the combination of IGF-I and FGF as well (Fig. 5, $A$ and $B)$. By contrast, the combination of EGF and FGF resulted in additive stimulation of DNA synthesis suggesting that their mitogenic signals proceed along distinct, noninteracting pathways (data not shown).

While the doubling times exhibited by the cells were significantly different, the time course for thymidine incorporation was similar for both groups $(22-32 \mathrm{~h})$. This time course is intermediate to the lengths of $\mathrm{Gl}$ exhibited by the two groups of cells (10-13 $\mathrm{h}$ and $40-47 \mathrm{~h}$ ). It has been previously shown that the ability of cells to be "rescued" from G0, reenter G1, and progress to $S$ phase frequently requires a longer period of time than it takes to traverse $G 1$ in sparse, exponentially growing cells (17). Moreover, the amount of time necessary to leave G0 and reenter $G 1$ varies with the length of time the cells are quiescent. This suggests that cellular quiescence resulting from density inhibition and serum starvation occurs at similar points in $\mathrm{G} 1$ before $\mathrm{S}$ phase in both groups of placental fibroblasts. The population of cells responsive to GF stimulation would there-

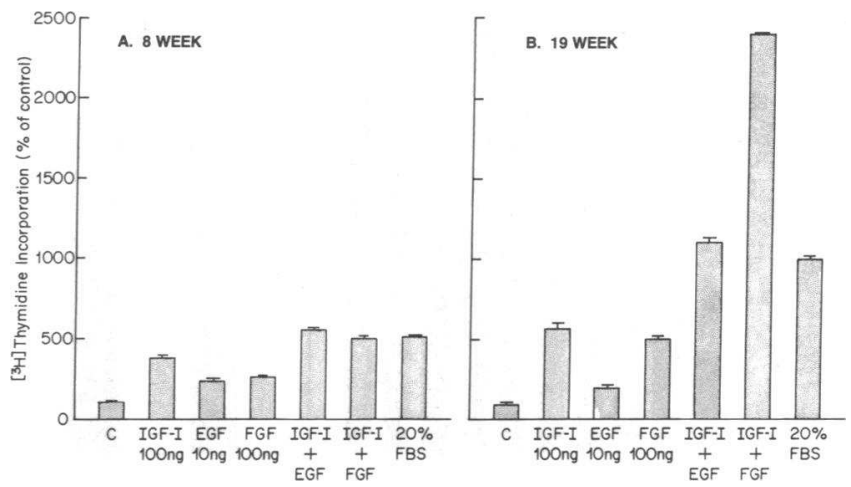

Figure 3. Effect of IGF-I $(100 \mathrm{ng} / \mathrm{ml})$, EGF $(10 \mathrm{ng} / \mathrm{ml})$, and FGF (100 $\mathrm{ng} / \mathrm{ml})$ on DNA synthesis in placental fibroblasts derived from: $(A)$ 8-wk placental tissue; and $(B)$ 19-wk placental tissue. Placental fibroblasts were grown and incubated with the indicated GFs and GF combinations as previously described. Data represent the average of three wells per treatment group \pm SEM. 


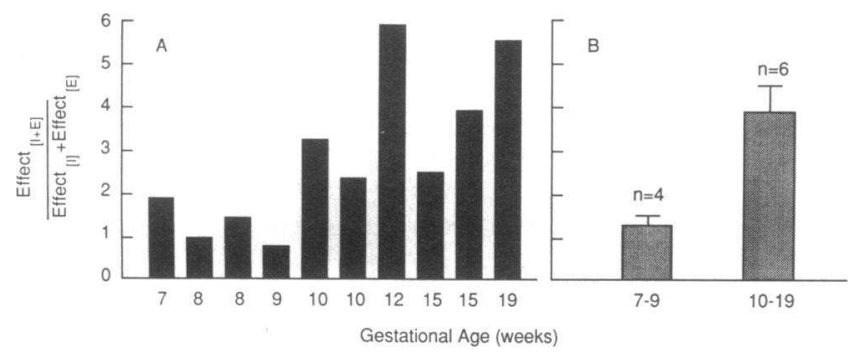

Figure 4. Potentiation of DNA synthesis by IGF-I/EGF interactions. Fibroblasts from different gestational ages were maintained in culture as previously described. Three wells were incubated with IGF-I (100 $\mathrm{ng} / \mathrm{ml})$ and EGF $(10 \mathrm{ng} / \mathrm{ml})$ alone. Three tandem wells were treated with IGF-I and EGF simultaneously. DNA systhesis resulting from the simultaneous addition of IGF-I and EGF was divided by the sum of the individual effects of IGF-I and EGF. This value is expressed as a single ratio. Purely additive effects would result in a ratio of 1 whereas synergistic effects would result in ratios $>1$. (A) Representative ratios from fibroblasts of different gestational ages. $(B)$ Ratios shown in $A$ were placed into two groups (7-9 wk, 10-19 wk) and averaged. The data represent the mean \pm SEM. The difference between the means of the two groups is statistically significant $(P<0.05)$.

fore reenter $\mathrm{Gl}$ at similar times relative to $\mathrm{S}$ phase and result in similar time courses of thymidine incorporation.

To determine the time during the cell cycle that the mitogenic pathways for IGF-I, FGF, and EGF interact, sequential addition experiments were performed on cells of 19 wk gestation. When IGF-I was added to the cells up to $8 \mathrm{~h}$ after FGF or EGF, maximal stimulation of DNA synthesis is observed. By contrast, if FGF or EGF is added after IGF-I, much less potentiation is observed (Fig. 6, $A$ and $B$ ). These data suggested that FGF and EGF act at a time early in the cell cycle to enhance the cellular responsiveness to IGF-I. This is consistent with the competence/progression model of cell cycle regulation previously put forth (18).

Cellular binding of $\left[{ }^{125} I\right]-I G F-I$ and $\left[{ }^{125} I\right]-E G F$. Cellular binding studies were performed to determine if the mitogenic pathways of IGF-I and EGF interact at the receptor binding

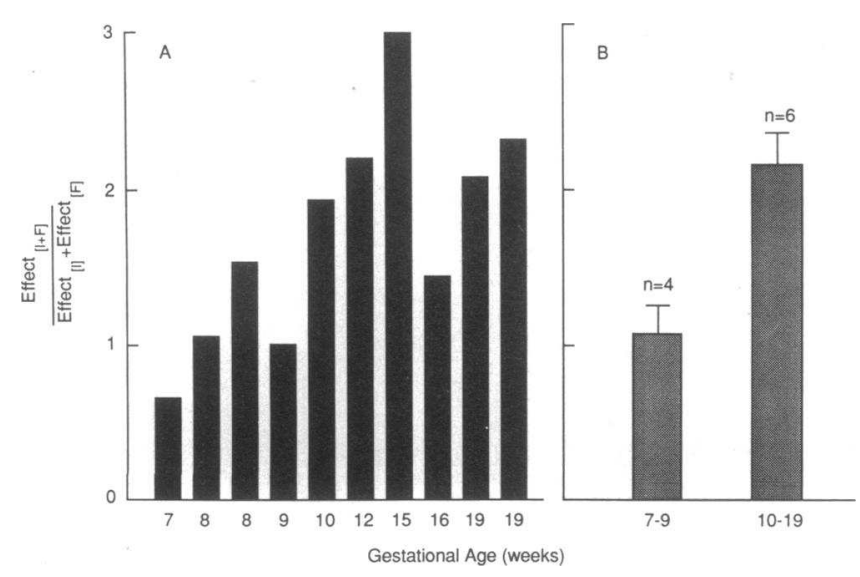

Figure 5, $A$ and $B$. Potentiation of DNA synthesis by IGF/FGF interactions. Placental fibroblasts were exposed to conditions identical to those described above, except FGF $(100 \mathrm{ng} / \mathrm{ml})$ was used instead of EGF. The difference between the means of the two groups is statistically significant $(P<0.05)$.

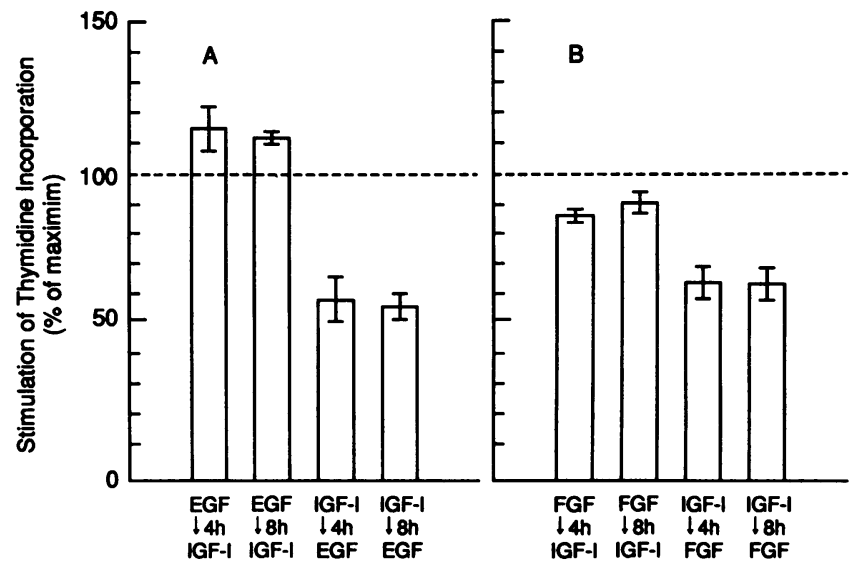

Figure 6. Effect of sequential addition of GFs on DNA synthesis. Placental fibroblasts of 19 wk gestation were grown and preincubated as previously described. $(A)$ At time $0 \mathrm{~h}$ IGF-I $(100 \mathrm{ng} / \mathrm{ml})$ and EGF $(10 \mathrm{ng} / \mathrm{ml})$ were added simultaneously to three wells. IGF-I and EGF each were added alone to tandem wells. At $4 \mathrm{~h}$ or $8 \mathrm{~h}$ IGF-I was added to the wells containing EGF without media change. Likewise, EGF was added to the wells containing IGF-I alone at $4 \mathrm{~h}$ or $8 \mathrm{~h}$. $\left[{ }^{3} \mathrm{H}\right]$-thymidine was then added at $26 \mathrm{~h}$ to all wells and the cells processed as described. Maximum stimulation was defined as the average thymidine uptake stimulated by the simultaneous addition of IGF-I and

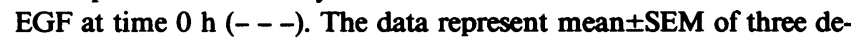
terminations. $(B)$ Identical experimental conditions described in $A$, except FGF $(100 \mathrm{ng} / \mathrm{ml})$ was substituted for EGF.

level. The cellular binding of [ $\left.{ }^{125} \mathrm{I}\right]-\mathrm{IGF}-\mathrm{I}$ and $\left[{ }^{125} \mathrm{I}\right]-\mathrm{EGF}$ to $19-$ wk cells was unaltered by the heterologous peptide during the course of these experiments (Table II). Additionally, dose-response analysis revealed no change in the $\mathrm{ED}_{50}$ of $\mathrm{EGF}(0.1-1.0$ $\mathrm{ng} / \mathrm{ml})$ or FGF $(5-15 \mathrm{ng} / \mathrm{ml})$ in the presence or absence of IGF-I. Likewise, the $\mathrm{ED}_{50}$ of IGF-I (20-30 ng/ml) was unaltered by the presence of EGF or FGF (data not shown).

${ }^{[25}$ I]-IGF-I was covalently crosslinked to 10 - and 15-wk placental fibroblasts and subjected to SDS-PAGE (Fig. 7). Autoradiography revealed no increase in labelling of the $\alpha$-subunit of the IGF-I receptor in the presence of EGF $(10 \mathrm{ng} / \mathrm{ml})$ or EGF $(100 \mathrm{ng} / \mathrm{ml})$. These data argue that the potentiation of GF interactions observed in these cells cannot be explained by the simple heterologous regulation of cellular binding capacity or affinity.

\section{Discussion}

The data presented in this report suggest that mesenchymal cells derived from human placental tissue undergo a developmental change resulting in an increased rate of proliferation,

Table II. Cellular Binding of $\left[{ }^{125} I\right]-I G F-I$ and $\left[{ }^{125} I\right]-E G F$ to Placental Fibroblast Monolayers

\begin{tabular}{lcc}
\hline \multicolumn{1}{c}{ Radioligand } & \multicolumn{1}{c}{$K_{\mathrm{d}}$} & B $_{\max }$ \\
\hline IGF-I (control) & $3.3 \times 10^{-10} \mathrm{M}$ & $2.6 \times 10^{-11} \mathrm{M}$ \\
IGF-I (EGF treated) & $3.8 \times 10^{-10} \mathrm{M}$ & $2.6 \times 10^{-11} \mathrm{M}$ \\
EGF (control) & $4.1 \times 10^{-10} \mathrm{M}$ & $5.7 \times 10^{-12} \mathrm{M}$ \\
EGF (IGF treated) & $4.9 \times 10^{-10} \mathrm{M}$ & $5.4 \times 10^{-12} \mathrm{M}$
\end{tabular}




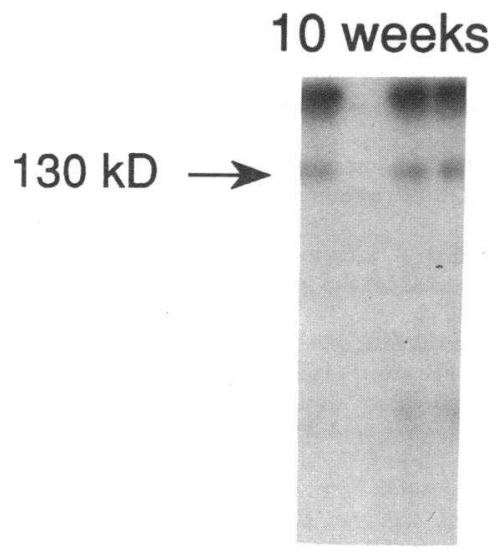

A B C D
15 weeks

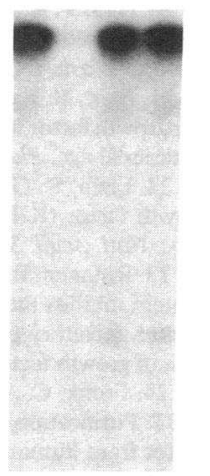

A B C D

Figure 7. The effect of EGF and FGF on [ $\left.{ }^{125} \mathrm{I}\right]-\mathrm{IGF}-\mathrm{I}$ binding. Placental fibroblasts ( 10 and 15 wk gestation) were grown to confluence. The cells were exposed to EGF $(10 \mathrm{ng} / \mathrm{ml})$ or FGF $(100 \mathrm{ng} / \mathrm{ml})$ for $4 \mathrm{~h}$. [ $\left.{ }^{125} \mathrm{I}\right]-$ IGF-I was covalently crosslinked to cell surface receptors as described and subjected to SDS-PAGE under reducing conditions. The gels were dried and exposed to $\mathrm{x}$-ray film for $4 \mathrm{~d}$. $(A)$ Control binding to untreated cells. $(B)$ Nonspecific binding in the presence of $200 \mathrm{ng} / \mathrm{ml}$ IGF-I. $(C)$ Binding to cells treated with EGF. (D) Binding to cells treated with FGF.

and is associated with an enhanced responsiveness to specific mitogenic signals. Interestingly, the appearance of this cellular phenotype, in vitro, is temporally related to the acceleration in fetal and placental growth that occurs at $\sim 10$ wk gestation (1). This acceleration in fetal growth occurs in several fetal organs including the placenta, and is due primarily to increased cell proliferation $(2,7)$. It is tempting to speculate, therefore, that the molecular basis of the phenotypic change in the placental fibroblasts represents a general and fundamentally important event in the progression of normal fetal development. If true, the stability of this phenotype in culture provides a unique opportunity to study the developmental regulation of the mitogenic response in the human.

Very little is now known regarding the mechanisms regulating fetal growth. Available evidence points to important roles for peptide growth factors during this period of rapid organ growth. Many fetal tissues have been shown to produce peptide GFs and GF receptors that may act locally to regulate cell growth and metabolism. We (5), and others (19), have reported that the human placenta produces IGFs (predominantly IGF-II) in mesenchymal cells that can act by autocrine or paracrine mechanisms to regulate placental function. Han et al. (20), provided further support for an autocrine/paracrine role for IGFs by demonstrating the general predominance of mRNA for both IGF-I and II in the mesenchyme of many fetal organs. Additionally, we have shown that the human placental mesenchyme produces IGF-specific binding proteins in a developmentally regulated manner (21). IGF binding proteins may act to modulate IGF bioactivity at the cellular level (22-23). It is likely, therefore, that altered expression of IGFs, IGF binding proteins, or IGF receptors can influence the mitotic activity of placental cells during gestation. The placenta also produces other peptide GFs, i.e., transforming growth factor- $\beta$ and platelet-derived growth factor-like peptides (24-25), that may likewise influence mitotic activity.
The data reported here support the concept that the ability of peptide GFs to elicit the mitogenic response is a function not only of the concentration of GF but also a function of the intrinsic cellular responsiveness to that specific GF or combination of GFs. The expression of factors that attenuate or augment GF signals are, therefore, likely candidates to regulate mitotic activity. Their altered expression throughout gestation may significantly alter the cellular response to mitogenic signals, in vivo. The inability of IGF-I or EGF to influence the cellular binding of the heterologous peptide suggests that the mitogenic pathways for each peptide interact at point(s) early in the cell cycle distal to the receptor binding site. The second messenger systems involved in mediating the mitogenic signal of each GF, therefore, are likely points of interaction and signal amplification. Interactions or "crosstalk" between signalling pathways have been well described in several cell culture systems (26-29). Additionally, protooncogenes have been closely linked to the proliferative response of cells and may function as important components of signalling pathways used by peptide GFs. Moreover, protooncogene expression occurs throughout embryonic and fetal development and does so in a tissue-specific and developmentally regulated manner (3, 4, 25, 30-33). The second messenger systems used by IGF-I, FGF, and EGF to elicit the mitogenic response in placental fibroblasts have not been defined. Characterization of these pathways should help delineate the molecular basis for the enhanced cellular response to their combined stimulation.

In summary, the proliferation rates of placental fibroblasts, in cell culture, bear a striking relationship to developmental age. Moreover, the appearance of rapidly dividing cells in culture coincides with the acceleration of fetal growth that begins at the end of the first trimester. This would suggest that accelerated fetal growth represents, in part, a developmental change intrinsic to some fetal cells. The cellular responsiveness to mitogenic growth factors also appears to be related to developmental age. While this increased responsiveness may account for part of the enhanced proliferative rate observed for these cells, the full complement of cellular mechanisms that determine this phenotype remain to be defined. The fact that the enhancement in proliferative rate and GF responsiveness are stable in cell culture provides an opportunity to define the cellular basis of this phenotype and, hopefully, delineate important mechanism(s) regulating normal fetal growth.

\section{Acknowledgments}

The author would like to thank the Cecil and Ida Green Center for Reproductive Biology Sciences for cooperation in obtaining placental tissues. The expert technical assistance of Ms. Jena Rogers is gratefully acknowledged as are the many useful discussions and support of Dr. B. Ozanne. The assistance of Dr. J. Kettman in performing the cell cycle analysis is also acknowledged.

This work was supported by grant HD22993, from the National Institute of Child Health and Human Development. Dr. Fant was the recipient of the Distinguished Young Investigator Award of the President's Research Council, University of Texas-Southwestern Medical Center, Dallas, Texas, which also supported this work.

\section{References}

1. Brenner, W. E., D. A. Edelman, and C. H. Hendricks. 1976. A standard of fetal growth for the USA. Am. J. Obstet. Gynecol. 126:555-564.

2. Widdowson, E. M., D. E. Crabb, and R. D. G. Milner. 1972. Cellular development of some human organs before birth. Arch. Dis. Child. 47:652-655. 
3. Adamson, E. D. 1987. Oncogenes in development. Development (Camb.). 99:449-471.

4. Slamon, D. J., and M. J. Cline. 1984. Expression of cellular oncogenes during embryonic and fetal development of the mouse. Proc. Natl. Acad. Sci. USA. 81:7141-7145.

5. Fant, M. E., H. N. Munro, and A. C. Moses. 1986. An autocrine/paracrine role for insulin-like growth factors (IGFs) in the regulation of human placental growth. J. Clin. Endocrinol. \& Metab. 63:499-505.

6. Boyd, J. D., and W. J. Hamilton. 1970. The Human Placenta. W. Heffer and Sons Ltd., Cambridge.

7. Gellen, J., and I. Gyori. 1969. The weight increase of the placenta and embryo in early human pregnancy. J. Obstet. Gynaecol. Br. Commonw. 76:990992.

8. Cunha, G. R., L. W. K. Chung, J. M. Shannon, O. Taguchi, and H. Fujii. 1983. Hormone-induced morphogenesis and growth: role of mesenchymal-epithelial interactions. Recent Prog. Horm. Res. 9:559-599.

9. Hern, W. M. 1984. Correlation of fetal age and measurements between 10 and 26 weeks of gestation. Obstet. Gynecol. 63:26-32.

10. Khong, T. Y., E. B. Lane, and W. B. Robertson. 1986. An immunohistochemical study of fetal cells at the maternal-placental interface using monoclonal antibodies to keratins, vimentin and desmin. Cell Tissue Res. 246:189-195.

11. Kliman, H. J., J. E. Nestler, E. Sermasi, J. M. Sanger, and J. F. Strauss. 1986. Purification, characterization, and in vitro differentiation of cytotrophoblasts from human term placentae. Endocrinology. 118:1567-1582.

12. Jaffe, E. A., R. L. Nachman, C. G. Becker, and C. R. Minick. 1973. Culture of human endothelial cells derived from umbilical veins. J. Clin. Invest. 52:2745-2756.

13. Hunter, W. M., and F. C. Greenwood. 1962. Preparation of iodine-131-labelled human growth hormone of high specific activity. Nature (Lond.). 194:495496.

14. Rechler, M. M., J. M. Podskalny, and S. P. Nissley. 1977. Characterization of the binding of multiplication stimulating activity (MSA) to a receptor for growth polypeptides in chick embryo fibroblasts. J. Biol. Chem. 252:3898-3910.

15. Crissman, H. A., and J. A. Steinkamp. 1986. Multivariate cell analysis: techniques for correlated measurements of DNA and other cellular constituents. In Techniques in Cell Cycle Analysis. J. W. Gray and Z. Darzynkiewicz, editors. Humana Press Inc., Clifton, NJ.

16. Gray, J. W., P. N. Dean, and M. L. Mendelsohn. 1979. Quantitative cell-cycle analysis. In Flow Cytometry and Sorting. M. R. Melamid, P. F. Mullaney, and M. L. Mendelsohn, editors. John Wiley and Sons, Inc., New York.

17. Rossini, M., J.-C. Lin, and R. Baserga. 1976. Effects of prolonged quiescence on nuclei and chromatin of WI-38 fibroblasts. J. Cell. Physiol. 88:1-12.

18. Pledger, W. J., C. D. Stiles, H. N. Antioniades, and C. D. Scher. 1977. Proc. Natl. Acad. Sci. USA. 74:4481-4485.

19. Wang, C.-Y., M. Daimon, S.-J. Shen, G. L. Engleman, and J. Ilan. 1988.
Insulin-like growth factor-I messenger ribonucleic acid in the developing human placenta and in term placenta of diabetics. Mol. Endocrinol. 2:217-228.

20. Han, V. K. M., A. J. D'Ercole, and P. K. Lund. 1987. Cellular localization of somatomedin (insulin-like growth factor) messenger RNA in the human fetus. Science (Wash. DC). 236:193-197.

21. Fant, M. E., H. N. Munro, and A. C. Moses. 1988. Production of insulinlike growth factor binding protein(s) (IGF-BP) by human placenta: variation with gestational age. Placenta. 9:397-407.

22. Elgin, R. G., W. H. Busby, and D. R. Clemmons. 1987. An insulin-like growth factor (IGF) binding protein enhances the biologic response to IGF-I. Proc. Natl. Acad. Sci. USA. 84:3254-3258.

23. Rutanen, E.-M., F. Pekonen, and T. Makinen. 1988. Soluble 34k binding protein inhibits the binding of insulin-like growth factor I to its cell receptors in human secretory phase endometrium: evidence for autocrine/paracrine regulation of growth factor action. J. Clin. Endocrinol. \& Metab. 66:173-180.

24. Frolik, C. A., L. L. Dart, C. A. Meyers, D. M. Smith, and M. B. Sporn. 1983. Purification and initial characterization of a type B transforming growth factor from human placenta. Proc. Natl. Acad. Sci. USA. 80:3676-3680.

25. Goustin, A. J., C. Betsholtz, S. Pfeifer-Ohlsson, H. Persson, J. Rydnert, M. Bywater, G. Holmgren, C.-H. Heldin, B. Westermark, and R. Ohlsson. 1985 Coexpression of the sis and myc proto-oncogenes in developing human placenta suggests autocrine control of trophoblast growth. Cell. 41:301-312.

26. Pfeifle, B., H. Boeder, and H. Ditschunert. 1987. Interaction of receptors for insulin-like growth factor I, platelet-derived growth factor, and fibroblast growth factor in rat aortic cells. Endocrinology. 120:2251-2258.

27. Rozengurt, E. 1986. Early signals in the mitogenic response. Science (Wash. DC). 234:161-166.

28. Rozengurt, E., and S. A. Mendoza. 1985. Synergistic signals in mitogenesis: role of ion fluxes, cyclic nucleotides and protein protein kinase C in Swiss 3T3 cells. J. Cell Sci. Suppl. 3:229-242.

29. Yoshimasa, T., D. R. Sibley, M. Bouvier, R. J. Lefkowitz, and M. G. Caron. 1987. Cross-talk between cellular signalling pathways suggested by phorbol-ester-induced adenylate cyclase phosphorylation. Nature (Lond.). 327:67-70

30. Mellersh, H., A. J. Strain, and D. J. Hill. 1986. Expression of the proto-oncogene c-H-ras and N-ras in early second trimester human fetal tissues. Biochem. Biophys. Res. Commun. 141:510-516.

31. Zimmerman, K. A., G. D. Yancopoulos, R. G. Collum, R. K. Smith, N. E Kohl, K. A. Denis, M. M. Nau, O. N. Witte, D. Toran-Allerond, C. F. Gee, et al. 1986. Differential expression of myc family genes during murine development. Nature (Lond.). 319:780-783.

32. Propst, F., and G. F. Vande Woude. 1985. Expression of c-mos protooncogene transcripts in mouse tissues. Nature (Lond.). 315:516-518.

33. Pfeifer-Ohlsson, S., A. S. Goustin, J. Rydnert, T. Wahlstrom, L. Bjersing, D. Stehelm, and R. Ohlsson. 1984. Spatial and temporal pattern of cellular myc oncogene expression in developing human placenta: implications for embryonic cell proliferation. Cell. 38:585-596. 